\title{
Introduction to Commentary on Universities and Science Communication
}

\section{Brian Trench}

Abstract

Keywords
The four essays in this Commentary examine contributions of universities to science communication's development but also challenges in consolidating those efforts.

History of public communication of science

Accounts of the growth of science communication, both in individual countries [e.g. Fleming and Star, 2017] and across regions and continents [e.g. Trench et al., 2014 ] give a central place to universities as locales of practice, education and research in this field. The establishment of university centres and programmes in science communication has been widely seen as a marker of its stabilisation and institutionalisation.

In this Commentary we look at universities' roles in science communication from several perspectives, through analysis of general trends and case studies. Within a broad view of science communication, ranging from dissemination of scientific information to embedding public dimensions of research into academic structures we distinguish the roles of universities in the following categories, some of which are examined in the following parts of this Commentary:

- employment of practitioners in institutional promotion, educational outreach, science exhibition and other forms of public engagement;

- (short-course) training of scientists and other researchers in public communication;

- (longer-form) degree programmes and mdules, at undergraduate and postgraduate levels;

- academic research, including PhD theses, in science communication and closely related topics;

- consultancy to external bodies in strategy, evaluation and training;

- civic engagement with stakeholders in research, its implications and directions. 
The four essays that follow consider: the contributions of universities to professionalisation in science communication, but also the contradictions that arise between different roles (Trench); new models of interdisciplinary research, focused on real-world issues and built around science communication (Wehrmann and Van der Sanden); integrating principles and practices of public engagement into the conduct and organisation of research (Holliman); case study of a university that does it all, including many activities that might elsewhere be done by cities or states (Nepote and Reynoso Haynes).

We have not given focused attention to universities' production of formal research; this is, at least indirectly, the topic of several surveys of publications in the field [e.g. Guenther and Joubert, 2017]. But, aside from the evidence of increased productivity, and the full pipeline, with increasing number of PhD projects - over 20 currently in one university alone ${ }^{1}$ — we might well ask whether science communication research is recognised by our peers and by those who allocate resources. Academic policy values formal research above other forms of practice, and science communication has struggled to demonstrate strongly enough intellectual rigour through world-leading research. In this context, notions of a 'science of science communication', as expounded in this journal [Kahan, 2015] and elsewhere, may appear attractive but requires careful and critical scrutiny.

Science communication is subject to short-term shifts in university priorities and financial management, and to the vagaries of personnel changes. There is much first-rate teaching, research and professional practice but academia is notoriously conservative in defining institutional structures. Many people working in science communication programmes admit they do not feel secure, and there are very few dedicated science communication centres or departments. The undoubted enthusiasm of university staff who teach, train, consult and research in the field is a major asset in our field. But we need also to influence top-level strategy and mid-level management of resources.

Author

Brian Trench is a researcher and trainer in science communication, formerly coordinator of the Masters in Science Communication at Dublin City University. He is co-editor with M. Bucchi of the Routledge Handbook of Public Communication of Science and Technology (2008 and 2014) and of Public Commmunication of Science, 4-voume anthology (Routledge, 2016), and with P. Murphy and D. Fahy of Little Country, Big Talk — science communication in Ireland (Pantaneto, 2017). He is president of the international PCST Network. E-mail: Brian.Trench@dcu.ie.

References

Fleming, J. and Star, J. (2017). 'The emergence of science communication in Aotearoa New Zealand'. JCOM 16 (3), A02. URL: https://jcom.sissa.it/archive/16/03/JC0M_1603_2017_A02.

Guenther, L. and Joubert, M. (2017). 'Science communication as a field of research: identifying trends, challenges and gaps by analysing research papers'. JCOM 16 (02), A02. URL: https://jcom.sissa.it/archive/16/02/JCOM_1602_2017_A02.

\footnotetext{
${ }^{1}$ Australian National University, Canberra - personal communication from Professor Joan Leach, director of the Centres for Public Awareness of Science at ANU
} 
Kahan, D. (2015). 'What is the "science of science communication"?' JCOM 14 (3), Y04. URL: https://jcom.sissa.it/archive/14/03/JCOM_1403_2015_Y04.

Trench, B., Bucchi, M., Amin, L., Cakmackci, G., Falade, B., Olesk, A. and Polino, C. (2014). 'Global spread of science communication: institutions and practices across continents'. In: Routledge Handbook of Public Communication of Science and Technology. Ed. by M. Bucchi and B. Trench. 2nd ed. London, U.K. and New York, U.S.A.: Routledge, pp. 214-230. DOI: 10.4324/9780203483794.

How to cite Communication'. JCOM 16 (05), C01. 